\title{
Long-Term Series of Chlorophyll- $a$ Concentration in Brazilian Semiarid Lakes from Modis Imagery
}

\author{
Dhalton Luiz Tosetto Ventura ${ }^{1, *}$, Jean-Michel Martinez ${ }^{2, *(D)}$, José Luiz de Attayde ${ }^{3}$, \\ Eduardo Sávio Passos Rodrigues Martins ${ }^{4}$, Nilva Brandini ${ }^{5}$ and Luciane Silva Moreira ${ }^{5}$ (D)
}

\section{check for}

Citation: Ventura, D.L.T.; Martinez, J.-M.; de Attayde, J.L.; Martins, E.S.P.R.; Brandini, N.; Moreira, L.S. Long-Term Series of Chlorophyll- $a$ Concentration in Brazilian Semiarid Lakes from Modis Imagery. Water 2022, 14, 400. https://doi.org/ $10.3390 / w 14030400$

Academic Editors: Monica Pinardi, Mariano Bresciani, Viktor Tóth and Igor Ogashawara

Received: 30 November 2021 Accepted: 31 December 2021 Published: 28 January 2022

Publisher's Note: MDPI stays neutral with regard to jurisdictional claims in published maps and institutional affiliations.

Copyright: (C) 2022 by the authors. Licensee MDPI, Basel, Switzerland. This article is an open access article distributed under the terms and conditions of the Creative Commons Attribution (CC BY) license (https:// creativecommons.org/licenses/by/ $4.0 /)$.
1 Brazilian National Water and Sanitation Agency, Brasilia 70610-200, Brazil

2 French National Research Institute for Sustainable Development, Edouard Belin, 31500 Toulouse, France

3 Ecology Department, Federal University of Rio Grande do Norte, Natal 59078-970, Brazil; cocattayde@gmail.com

4 Research Institute in Meteorology and Water Resources, Fortaleza 60115-221, Brazil; espr.martins@gmail.com

5 Chemistry Institute, Fluminense Federal University, Rio de Janeiro 24020-141, Brazil; nbrandini@gmail.com (N.B.); lucianebiouff@gmail.com (L.S.M.)

* Correspondence: dhalton.ventura@ana.gov.br (D.L.T.V.); martinez@ird.fr (J.-M.M.)

Abstract: By monitoring the chlorophyll a concentration (chla), it is possible to keep track of the eutrophication status of a lake and to describe the temporal dynamics of the phytoplankton biomass. Such monitoring must be both extensive and intensive to account for the short- and long-term biomass variations. This may be achieved by the remote estimation of chla through an orbital sensor with high temporal resolution. In this study, we used MODIS imagery to produce 21-year time series of chla for three strategic lakes of the Brazilian semi-arid region: Eng. Armando Ribeiro Gonçalves, Castanhão, and Orós. We used data collected in 13 lakes of the region to test new and published regression models for chla estimation. The selected model was validated and applied to daily MODIS images for the three largest lakes. The resulting chla time series revealed that the temporal dynamics of the phytoplankton biomass is associated with the hydraulic regime of the lakes, with chla plummeting upon intense water renewal and keeping high during persistent dry periods. The intense rainy season of 2004 reduced the phytoplankton biomass and its effects even extended to the subsequent years. Our results encourage the exploration of the MODIS archived imagery in limnological studies.

Keywords: algal biomass; remote sensing; satellite; water quality; drylands; reservoirs

\section{Introduction}

Eutrophication has affected lakes all over the world, with several negative consequences in the ecological, economical, and sanitary areas, such as shifts in the phytoplankton composition, higher treatment costs for drinking water, and the frequent growth of potentially toxic cyanobacteria [1,2]. These consequences are associated with an exaggerated increase in the phytoplankton biomass, for which a common and reliable proxy is the chlorophyll a concentration (chla) [3]. By monitoring chla it is possible to keep track of the eutrophication status of a water body and to describe the temporal dynamics of the phytoplankton biomass.

Ideally, a monitoring program should be extensive for long-term data is necessary to evaluate the effects of climate and large-scale phenomena [4,5], and also intensive, for only high-frequency sampling can account for the significant biomass fluctuations that the phytoplankton may exhibit in a matter of days [6,7]. Such a complete monitoring program is rarely achieved, however, because of the costs that are related to sampling [8]. A viable alternative, which warrant both intensive and extensive data series, is the remote sensing of chla through orbital sensors with high temporal resolution, such as the MODIS sensor, which covers most of the globe daily and has been operating since 2000 [9]. There are orbital sensors with better spatial or spectral resolution, such as OLI/Landsat 8, MSI/Sentinel-2, 
and OLCI/Sentinel-3, but they have worse temporal resolution or shorter time series. The MODIS image archive is the only offering long-term series of daily global coverage. The daily revisit greatly increases the chance of getting cloud-free images.

There are two MODIS sensors aboard of NASA satellites. One, that is aboard Terra, has been operating since 2000. The second, in the Aqua satellite, has been operating since 2002. The life expectancy of both satellites has been far exceeded, so the operation of the MODIS sensors may end soon. But the image archive that has been produced so far is quite valuable and can be transformed into a comprehensive time series of water quality parameters. For example, a decade-long time series of suspended sediments were generated from MODIS imagery for Lake Taihu (China) [10] and for the Ucayali River (Peru) [11]. In addition, long-term water clarity time series were produced from MODIS imagery for 153 lakes in China [12].

MODIS data has been successfully used to estimate chla in oceanic waters thanks to its bands 8 to 16, which were designed for ocean color, phytoplankton, $\mathrm{n}$ and biogeochemistry applications [13,14]. A study in the Caspian Sea revealed a progressive eutrophication trend from 2003 through 2017 from a MODIS-based chla product [15]. Yet the application of the bands 8-16 to small and mid-sized water bodies is limited by their coarse spatial resolution $(1000 \mathrm{~m})$ and their vulnerability to saturation [16,17]. The MODIS bands 1 to 7 were designed for land applications, being less subject to saturation. Their better spatial resolution (250-500 m) encourages their application to inland water bodies. Novo et al. [18] developed an empirical model that was built by means of linear spectral unmixing, for predicting chla in Amazonian lakes from the reflectance in the MODIS bands 1-7. Zhang et al. [19] proposed an empirical model for prediction of chla in Lake Taihu from the reflectance in MODIS band 2 (near infrared). Ogashawara et al. [20] developed a multiple linear regression with the MODIS bands 1 (red), 4 (green), 5 (near/mid infrared), and 6 (mid infrared) for prediction of chla in the Itumbiara lake, a man-made lake in Brazil. Lins et al. [21] developed and validated an empirical model that was based on the near-infrared-red ratio to predict chla in two lagoons in Northeastern Brazil. Their model was applied to a 2000-2016 series of MODIS 8-day composite images and allowed them to evaluate the influence of environmental variables on chla spatiotemporal variability. Zhang et al. developed an algorithm named BNDBI (baseline normalized difference bloom index) [22], a calculation of the normalized difference between the heights of the MODIS bands 4 and 1 over a baseline between the bands 3 (blue) and 2. It was validated for a chla range of $10-1000 \mu \mathrm{g} / \mathrm{L}$ in Lake Chaohu.

Considering MODIS's temporal resolution and its potential application to the study of the phytoplankton biomass' temporal dynamics, we aimed at selecting an algorithm that was applicable to daily MODIS images and retrieving long-term chla time series in lakes of the Brazilian semiarid region. Due to its climate and to frequent droughts, water supplying in the region is highly dependent upon the water that is stored in man-made lakes. Yet, despite such dependence, many of those lakes have unsatisfying water quality because of eutrophication [23-26]. Chla assessment is infrequent or even absent in many lakes, so the remote estimation of such parameter on a daily scale is of great utility for the region. Using data that was collected in 13 lakes of the region, we tested new and published algorithms and applied the selected one to MODIS images, generating 21-year series of chla in three strategic lakes of the region: Eng. Armando Ribeiro Gonçalves, Castanhão, and Orós.

\section{Materials and Methods}

\subsection{Study Sites}

The Brazilian semiarid region extends over 1.189 cities of nine states. Its climate is characterized by a low annual precipitation $(<900 \mathrm{~mm})$, a high potential evapotranspiration (>2000 $\mathrm{mm}$ ), and a high spatiotemporal variability of the precipitation, both within and between the rainy seasons [27-29]. The rainy season is generally concentrated in two or three months between January and July [30]. Extreme rainfall events occasionally occur and account for a significant proportion of the annual precipitation [29]. The region is also 
characterized by severe droughts that may last several years. Because most streams are naturally intermittent, water supply in the region relies on the water that is stored in manmade lakes. Many of these lakes have poor water quality due to eutrophication, facilitated by a combination of long water residence times ( $>1$ year), high water temperatures $\left(>25^{\circ} \mathrm{C}\right)$, high insolation throughout the year, and high nutrient loads due to soil erosion and discharge of agro-pastoral effluents and domestic sewage [30].

We used data that was collected from 13 lakes of the region (Table 1, Figure 1). The use of data from several lakes is justified by the need of having an as-wide-as-possible range of chlorophyll-a concentration (chla) for model fitting and validation, as well as by the benefit of having a more generic predictive model, possibly applicable to other lakes of the region. The study sites include small, intermediary, and large lakes, with a water surface area ranging from 1.85 to $441 \mathrm{~km}^{2}$ and a storage capacity ranging from 38 to $6700 \mathrm{hm}^{3}$. Similar to most man-made lakes of the Brazilian semiarid region, these lakes are shallow and warm lakes, with temperatures that are higher than $23^{\circ} \mathrm{C}$ and commonly around $30{ }^{\circ} \mathrm{C}[30,31]$. They are also characterized by long water residence times ( $>1$ year) [30]. Due to the high spatial and temporal variability in the regional precipitation, the lakes are subject to high variability in water inflow and outflow. Most of these lakes are critical for local or regional water supply.

Table 1. Study lakes in the Brazilian semiarid region.

\begin{tabular}{|c|c|c|c|c|c|}
\hline Lake & ID & $\begin{array}{c}\text { Surface Area } \\
\left(\mathbf{k m}^{2}\right)\end{array}$ & $\begin{array}{c}\text { Storage Capacity } \\
\left(\mathrm{hm}^{3}\right)\end{array}$ & $\begin{array}{l}\text { Mean Depth } \\
(\mathrm{m})\end{array}$ & $\begin{array}{c}\text { Location } \\
\text { (Coordinates) }\end{array}$ \\
\hline Castanhão & CAST & 441.00 & 6700 & 15 & $5.500^{\circ} \mathrm{S}, 38.470^{\circ} \mathrm{W}$ \\
\hline Orós & OROS & 350.00 & 1940 & 6 & $6.250^{\circ} \mathrm{S}, 38.940^{\circ} \mathrm{W}$ \\
\hline Eng. Armando Ribeiro Gonçalves & EARG & 195.00 & 2400 & 12 & $5.690^{\circ} \mathrm{S}, 36.880^{\circ} \mathrm{W}$ \\
\hline Banabuiu & BANB & 102.00 & 1700 & 17 & $5.360^{\circ} \mathrm{S}, 38.950^{\circ} \mathrm{W}$ \\
\hline Pedras Brancas & PEDB & 72.88 & 434 & 6 & $5.130^{\circ} \mathrm{S}, 38.880^{\circ} \mathrm{W}$ \\
\hline Pacoti & PACT & 37.00 & 370 & 10 & $4.040^{\circ} \mathrm{S}, 38.540^{\circ} \mathrm{W}$ \\
\hline Pacajus & PACJ & 35.56 & 240 & 7 & $4.220^{\circ} \mathrm{S}, 38.400^{\circ} \mathrm{W}$ \\
\hline Santa Cruz do Apodi & SCAP & 34.13 & 600 & 18 & $5.770^{\circ} \mathrm{S}, 37.810^{\circ} \mathrm{W}$ \\
\hline Umari & UMAR & 29.23 & 293 & 10 & $5.700^{\circ} \mathrm{S}, 37.240^{\circ} \mathrm{W}$ \\
\hline Piató Lake & PIAT & 15.53 & 96 & 6 & $5.520^{\circ} \mathrm{S}, 36.940^{\circ} \mathrm{W}$ \\
\hline Aracoiaba & ARAC & 15.06 & 171 & 11 & $4.400^{\circ} \mathrm{S}, 38.710^{\circ} \mathrm{W}$ \\
\hline Mendobim & MEND & 9.70 & 76 & 8 & $5.650^{\circ} \mathrm{S}, 36.932^{\circ} \mathrm{W}$ \\
\hline Malcozinhado & MALC & 1.85 & 38 & 21 & $4.108^{\circ} \mathrm{S}, 38.295^{\circ} \mathrm{W}$ \\
\hline
\end{tabular}

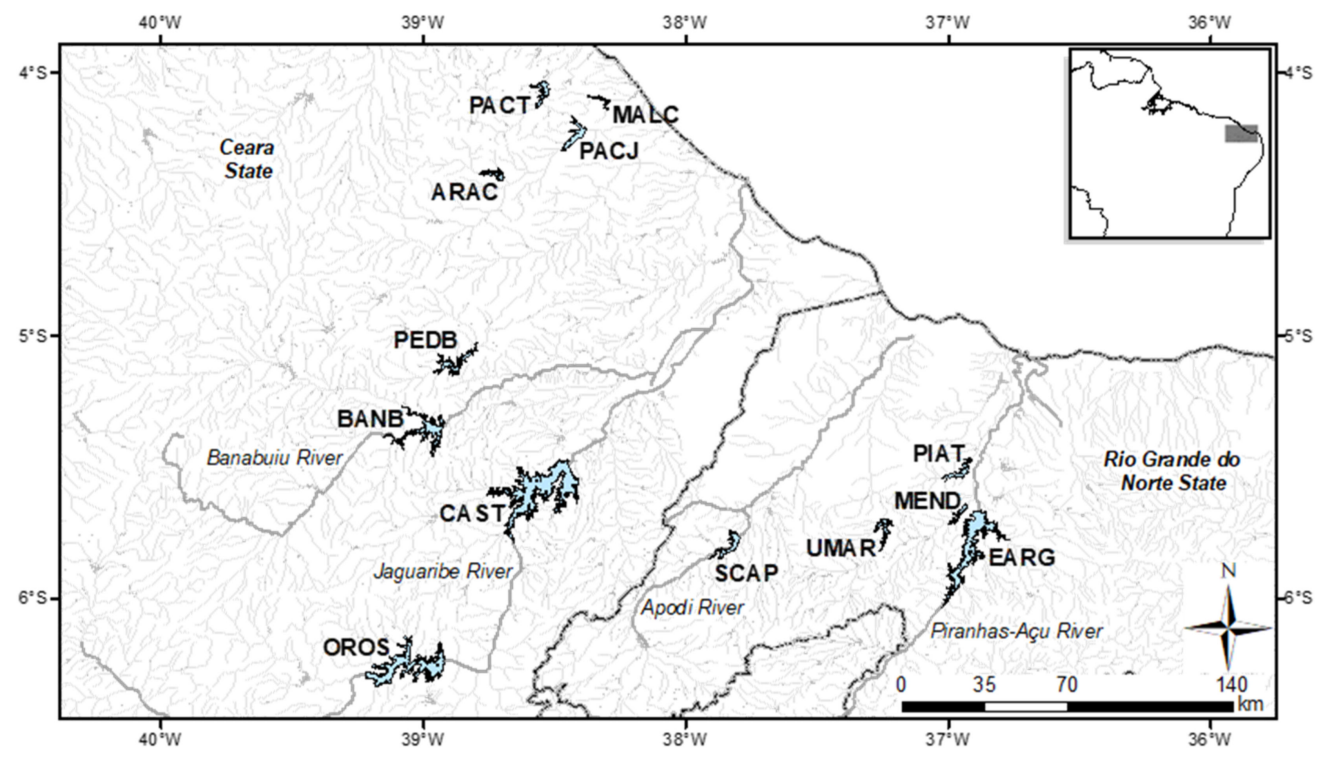

Figure 1. Location of the 13 study lakes (Table 1) in the Brazilian semiarid region (Ceará and Rio Grande do Norte states). 


\subsection{Field Data}

A total of five datasets were used in this study, conveniently named as Datasets 1-5 (Table 2). Datasets 1 and 2 contain data of surface chla and the reflectance in the MODIS bands 1-4 that were simulated from field remote sensing reflectance spectra (Figure S1). They were tested for model fitting or validation whereas the others were only used for validation. Dataset 1 also includes the concentration of surface suspended solids (SSS) and surface inorganic suspended solids (ISS) data. Its data were collected during seven field trips, the first in November 2008 and the last in August 2013, in the lakes CAST, EARG, MEND, OROS, PACJ, PACT, and SCAP. The analyses were performed in the Laboratory of Aquatic Ecology of the Department of Ecology of the Federal University of Rio Grande do Norte (LEA/UFRN). Dataset 2 was collected during a field campaign in November 2015 in the following lakes: ARAC, CAST, EARG, OROS, PACJ, PACT, PEDB, SCAP, and UMAR. The analyses took place in the Geochemistry Laboratory of the Federal Fluminense University (UFF). Dataset 3 is a synthetic chla dataset that was generated through the application of a three-band predictive model $\left(\mathrm{r}^{2}=0.99\right.$, Figure S2) to the remote sensing reflectance data that were collected during the same field trips of Dataset 1 and 2. Dataset 4 derives from observational studies that were conducted by the Federal University of Rio Grande do Norte and is composed of monthly data that were collected in EARG from Jul, 2006 through June 2008 and analyzed in LEA/UFRN. Due to the imprecision of the informed date of collection, we discarded from Dataset 4 the data from Nov./2006-Jan./2007, Mar.-May/2007, Jul.-Aug./2007, and Mar./2008. Finally, Dataset 5 was made available by the Water Resources Management Company (Cogerh) of Ceará state and is composed of data from their regular water quality monitoring program and from specific field trips covering the 2004-2021 period and including the lakes CAST, OROS, PACJ, PACT, BANB, and MALC.

Table 2. Descriptive statistics of the five datasets that were used for model fitting or validation. Chlorophyll-a (chla) is in micrograms per liter ( $\mu \mathrm{g} / \mathrm{L})$, whereas surface suspended solids (SSS) and surface inorganic suspended solids (ISS) are in milligrams per liter (mg/L).

\begin{tabular}{lccccccc}
\hline Statistics & Chla & $\begin{array}{c}\text { Dataset 1 } \\
\text { SSS }\end{array}$ & ISS & $\begin{array}{c}\text { Dataset 2 } \\
\text { Chla }\end{array}$ & $\begin{array}{c}\text { Dataset 3 } \\
\text { Chla }\end{array}$ & $\begin{array}{c}\text { Dataset 4 } \\
\text { Chla }\end{array}$ & $\begin{array}{c}\text { Dataset 5 } \\
\text { Chla }\end{array}$ \\
\hline $\mathrm{n}$ & 73 & 48 & 37 & 18 & 72 & 47 & 219 \\
min & 0.2 & 0.5 & 0.0 & 1.6 & 0.0 & 7.2 & 0.0 \\
median & 38.4 & 8.2 & 0.5 & 33.0 & 51.5 & 51.4 & 10.4 \\
mean & 37.4 & 10.3 & 2.6 & 30.9 & 51.1 & 48.3 & 18.1 \\
max & 101.0 & 39.0 & 18.7 & 68.0 & 229.9 & 82.3 & 251.6 \\
std. dev. & 25.8 & 8.1 & 5.2 & 21.5 & 41.6 & 21.2 & 27.7 \\
\hline
\end{tabular}

In the larger lakes, there were three or more sampling points for determination of chla, whereas in the smaller lakes there were one or two sampling points. The points were positioned as far from the borders as possible. At each sampling point, two $500 \mathrm{~mL}$ plastic bottles were filled with subsurface water and stored in a dark isothermal box with ice until later in the evening when each subsample was separately vacuum filtered. The samples that were processed at the LEA/UFRN laboratory (Datasets 1 and 4) were filtered using borosilicate glass membranes of $1.2 \mu \mathrm{m}$ pore size. The samples that were processed at the laboratories that were associated with UFF and Cogerh (Datasets 2 and 5 ) were filtered using cellulose acetate membranes of $0.45 \mu \mathrm{m}$ pore size. The membrane filters were kept frozen in a dark flask with silica gel for later chlorophyll $a$ extraction in the laboratory (LEA/UFRN: 96\% ethanol; UFF and Cogerh: 90\% acetone). In the LEA/UFRN and UFF analyses, the extract was not acidified for pheophytin $a$ estimation, in accordance with Stich \& Brinker's [32] conclusion that the non-pheophytin-corrected samples were more accurate than the corrected (acidified) ones. The concentration was determined spectrophotometrically [LEA/UFRN: Jespersen \& Christoffersen [33]; UFF: Jeffrey \& Humphrey [34]; Cogerh: APHA, AWWA \& WEF [35]]. As for the solid analyses 
(SSS and ISS, Dataset 1), Whatman 934-AH membrane filters that were previously weighted and dried, were used to vacuum filter the water samples. They were dried once more $\left(105^{\circ} \mathrm{C}\right.$ for $\left.24 \mathrm{~h}\right)$ and weighted for determining SSS. Part of these filters was glowed in a muffle furnace at $500{ }^{\circ} \mathrm{C}$ for $3 \mathrm{~h}$ and weighted again for determination of ISS.

Nearly simultaneous to the water sampling, radiometric data was collected through a set of three TriOS RAMSES hyperspectral radiometers that were mounted on the boat. Following the Mobley [36] protocol, the irradiance and radiance were measured in the range 400-900 nm, with a resolution of $3.3 \mathrm{~nm}$, and instantaneously combined in the TriOS MSDA application to produce the corresponding spectrum of remote sensing reflectance, calculated at each wavelength as $R_{r s}=\left(L_{u}-L_{d} \times 0.028\right) / E_{d}$, where $E_{d}$ is the downwelling solar irradiance, $L_{u}$ is upwelling radiance, and $L_{d}$ is the downwelling radiance. The MODIS spectral response function was then applied to the reflectance spectra to simulate the reflectance in the MODIS bands $1-4$. The simulated MODIS bands were rescaled by being multiplied by $p i \times 10^{4}$.

The samples of Dataset 2 were also analyzed for the absorption coefficient of the seston and of the CDOM (colored dissolved organic matter) in the 400-700 nm range. The measurements were taken with a TriOS OSCAR hyperspectral absorption meter. We first measured the total absorption coefficient of the unfiltered sample and then repeated the measurement with the sample filtered through a $0.45 \mu \mathrm{m}$ membrane filter. The latter corresponded to the CDOM absorption and its difference to the total absorption corresponded to the seston absorption.

Finally, time series of daily water storage and inflow of the lakes were obtained from the Brazilian National Water and Sanitation Agency (ANA) and the National Department for Works Against Drought (DNOCS). Daily gaps were filled by linear interpolation. The daily water renewal rate of a lake was calculated as the daily water inflow divided by the stored volume.

\subsection{MODIS Data}

For model validation and time series generation, we used the collection 6 of the products MOD09GA and MYD09GA, which are atmospherically corrected 500-m spatial resolution images with seven bands in the visible and infrared regions, and with layers containing, for each pixel, information on the quality of the data acquisition [37]. All the lakes were located within the tile h14v09 of the MODIS sinusoidal grid.

The images were accessed through the Google Earth Engine (GEE) platform [38], which provides, for noncommercial purposes, free access and processing of an extensive catalog of image archives, encompassing some of the most important orbital sensors of past and present days. Processing requests were executed through the GEE Python API. A script named GEEDaR (Google Earth Engine Data Retriever) was developed to facilitate the automation of the requests. Basically, for each site and sampling date, it extracted the median water reflectance values within polygons representing the areas of interest. When extracting the reflectance data for model fitting and validation, the smaller lakes had a single polygon comprising the area near the dam and the intermediary portion of the lake, whereas the larger lakes had two to three polygons: one delimiting the dam region, other delimiting the intermediary portion of the lake, and, in the EARG lake, a third in the region of the main river inflow. When extracting data for time series generation, only the polygon that was close to the dam was used. A total of 185,978 image subsets were processed.

Before the calculation of the median reflectance at each band, a pixel selection procedure was adopted to keep only the reliable water pixels. First, the pixels that were classified in the layer State_1 km ("surface reflectance Data State QA") as affected by cloud, aerosol, or shadow, were masked. Then k-means clustering (2-20 clusters) was applied to the MODIS bands 1 and 2 (red and near infrared) and the cluster with the lowest NDVI was chosen. In sequence, a simple reflectance correction that was proposed by Wang et al. [39] was applied to the selected pixels and the median reflectance was calculated for bands 1-7. Additionally, a simple quality flag varying from 1 to 3 was attributed to that record, based 
on the sensor view angle, the sunlight propensity, the proportion of valid pixels, and the mean reflectance in the near infrared. Only data of quality 1 and 2 were used. Due to face that MODIS' low spatial resolution causes a significant spectral mixture, these steps were important to maximize the chances of getting reflectance values that were representative of the water leaving reflectance.

\subsection{Modelling}

For model fitting, in situ reflectance and chla records were paired and tested separately for Datasets 1 and 2, whereas for model validation the MODIS median reflectance that was extracted from the areas of interest was paired to the chla data in the same area (Datasets 1-5). Only images of the same date as the field sampling were considered. Through an $\mathrm{R}$ script, one- and two-variable regression models were built upon 3306 combinations of simple and complex spectral indices, such as single bands, band ratios, band differences, second-derivative, and other calculations. In addition to simple linear models, we tested log-linear and log-log-models by log-transforming the data and then used the equivalent exponential and power equations in the validation step. We also tested the published models and algorithms, as described below. Models with $r^{2} \geq 0.5$ were then tested against the validation dataset, which is the aggregation of all the datasets that were not used for model fitting. The models were then sorted by the validation $r^{2}$ and only those with $r^{2} \geq 0.4$ were considered. The root mean square error (RMSE) was calculated for each model.

The list of tested models and algorithms from the literature (Table 3) included some that were applied to land products of MODIS [19,21] and Landsat [40-43]. The relevant algorithms that were available in the literature, such as the 3- and 4-band algorithms [44,45] were not tested because the width and position of the MODIS's land bands are not compatible with such algorithms that were designed for sensors like MERIS and OLCI. We did, however, test the BNDBI algorithm [22], which was developed from bio-optical simulations and was validated for a wide range (10-1000 $\mu \mathrm{g} / \mathrm{L})$ of chla in Lake Chaohu. They used reflectance values that were corrected only for the Rayleigh scattering, whereas we used fully atmospherically corrected imagery. These models and algorithms were tested both with and without the reflectance correction that was proposed by Wang et al. [39].

Table 3. Regression models for the estimation of chlorophyll-a concentration that was tested in this study. The models' result and the RMSE values are in micrograms per liter ( $\mu \mathrm{g} / \mathrm{L})$. B, G, R, and IR stand for the reflectance at the blue, green, red, and near infrared bands.

\begin{tabular}{|c|c|c|c|c|c|}
\hline$\#$ & Tested Model & $\mathbf{n}$ & $\mathbf{r}^{2}$ & RMSE & Ref. \\
\hline 1 & $9.17-44 \times \mathrm{IR}+9800 \times \mathrm{IR}^{2}$ & 145 & 0.907 & 7.48 & [19] \\
\hline 2 & $10 \times(\mathrm{IR} / \mathrm{R})^{1.8416}$ & 26 & 0.83 & 15.24 & [21] \\
\hline 3 & $104,401.57 \times \mathrm{R}^{1.9742}$ & 16 & 0.954 & - & [40] \\
\hline 4 & $6.71+0.0537 \times \mathrm{B}-1.559 \times \mathrm{B} / \mathrm{R}$ & 15 & 0.88 & - & [41] \\
\hline 5 & $21.79-0.1675 \times \mathrm{B}-3.855 \times \mathrm{B} / \mathrm{G}$ & 15 & 0.86 & - & [41] \\
\hline 6 & $63.434+153.778 \times B-803.31 \times G+239.639 \times R$ & 44 & 0.71 & - & [42] \\
\hline 7 & $49.057+63.832 \times \mathrm{B}-236.05 \times \mathrm{G}-110.046 \times \mathrm{IR}$ & 44 & 0.73 & - & [42] \\
\hline 8 & $49.428-183.033 \times \mathrm{G}-103.798 \times \mathrm{IR}$ & 44 & 0.73 & - & {$[42]$} \\
\hline 9 & $51.922-366.287 \times \mathrm{G}+184.622 \times \mathrm{R}-116.926 \times \mathrm{IR}$ & 44 & 0.74 & - & [42] \\
\hline 10 & $54.658+520.451 \times B-1221.89 \times G+611.115 \times R-198.199 \times I R$ & 44 & 0.77 & 6.32 & [42] \\
\hline 11 & $1.31+0.64 \times\left(G / B^{2}\right)$ & 85 & 0.84 & 1.78 & [43] \\
\hline 12 & $6.6+79.05 \times \mathrm{BNDBI}+562.4 \times \mathrm{BNDBI}^{2}+71.86 \times \mathrm{BNDBI}^{3}+982.3 \times \mathrm{BNDBI}^{4}$ & 114 & 0.925 & 1.82 & [22] \\
\hline
\end{tabular}

For models 1 and 3 , the reflectance values were divided by pi $\times 10^{4}$. BNDBI is the difference between the heights of the reflectance in red and green bands over a baseline from the blue to the near infrared bands.

\subsection{Time Series}

The model with the best validation result was selected and applied to the MODIS imagery to generate a time series of daily chla from 2000 through 2020 in the three largest study lakes: EARG, CAST, and OROS. As previously explained, the median reflectance was calculated for the lake's area near the dam and only data with a quality flag 1 or 2 were used. 
When both the Aqua and Terra were available, the median chla was calculated. The daily estimated concentrations were then used to determine the yearly frequency of trophic states in each lake. A threshold of $15 \mu \mathrm{g} / \mathrm{L}$ was considered to separate two classes: mesotrophic and eutrophic. Such a threshold corresponds to the lower limit that is suggested for the eutrophic class in waters of semiarid man-made lakes [46] and is also close to the limit $(10 \mu \mathrm{g} / \mathrm{L})$ that is suggested for subtropical and tropical lakes [47]. The chla time series were also analyzed in comparison to the lakes' series of stored water to qualitatively evaluate the influence of water renewal and droughts.

\section{Results}

\subsection{Optical Properties}

The lakes differed in their limnological properties, such as their contents of chlorophyll $a$ (chla)—some were mesotrophic, such as Santa Cruz do Apodi (mean chla $=6 \mu \mathrm{g} / \mathrm{L}, \mathrm{n}=7$ ), and others were clearly eutrophic, such as Eng. Armando Ribeiro Gonçalves (EARG) (mean chla $=52, \mathrm{n}=37$ ) —and inorganic suspended solids (ISS), which varied among the lakes and sampling sites. Such variability was, in fact, important for us to be able to seek an algorithm that was applicable to variable limnological conditions. On the other hand, their optical properties were similar enough to allow for the adoption of a single chla estimation model, as evidenced by seston and CDOM absorption measurements. As most reflectance spectra (Figure S1) featured a conspicuous cavity around $680 \mathrm{~nm}$ followed by a peak around $700 \mathrm{~nm}$, we used the difference in the seston absorption coefficients at 680 and $700 \mathrm{~nm}$ as an indicator of the chlorophyll $a$ concentration. And, in fact, both variables were highly correlated $\left(\mathrm{r}^{2}=0.96, \mathrm{n}=19\right)$. Also important, the CDOM absorption coefficient at $440 \mathrm{~nm}$ was similar among the lakes, ranging from 0.44 to $0.93 \mathrm{~m}^{-1}\left(\right.$ mean $\left.=0.74 \mathrm{~m}^{-1}, \mathrm{n}=19\right)$.

\subsection{Modis Data Evaluation}

A comparison between the field and satellite reflectance indicates that the adopted algorithm for pixel selection and reflectance correction was effective (Figure 2, 78 images, $\left.r^{2}=0.67\right)$. The large dispersion that was observed in the graph was expected due to the scale differences between the point measurements of field radiometry and the broad coverage of the MODIS pixels, as well as to the limitations in the correction of atmospheric and adjacency effects. The adjustment is satisfactory for the visible bands and degraded for the near infrared.

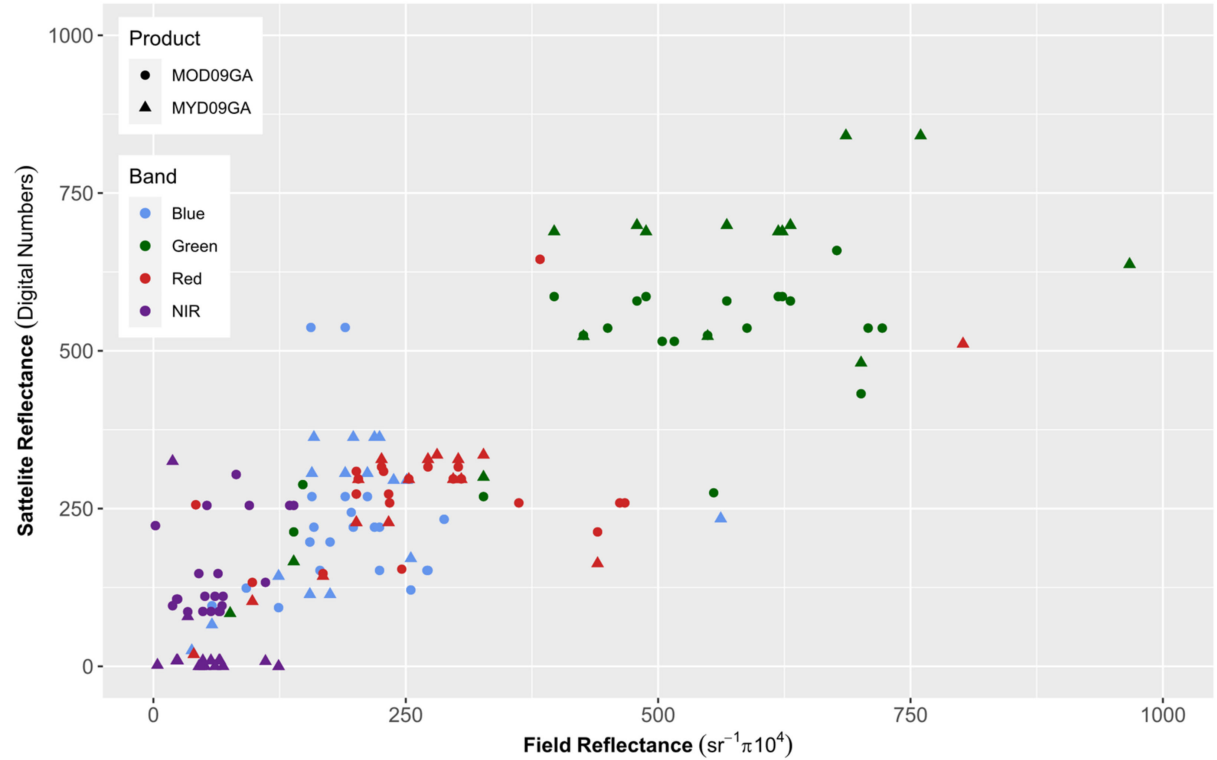

Figure 2. Reflectance that was extracted from subsets of MODIS products MOD09GA and MYD09GA compared to the reflectance that was measured in the field at the same day (78 images, $\left.\mathrm{r}^{2}=0.67\right)$. The field reflectance data was collected with hyperspectral radiometers and used to simulate the MODIS bands 1 (red), 2 (near infrared), 3 (blue), and 4 (green). 


\subsection{Modelling}

A total of 1394 models had $\mathrm{r}^{2} \geq 0.5$ and were tested against the validation dataset (all the datasets, except for the one that was used in the model fitting). Only 7 were validated with $\mathrm{r}^{2} \geq 0.4$, all of them built upon bands and indices involving the green and red bands (Table 4). Several models were fitted from the field reflectance data with $\mathrm{r}^{2} \geq 0.9$ (e.g., Figure S3) but none were successful in validation. Fitting and validation of the selected model (\#1) is presented below (Figure 3). All the models from the literature (Table 3) had $\mathrm{r}^{2}<0.1$ and were discarded.

Table 4. Regression models for chlorophyll- $a$ (chla) estimation, in $\mu \mathrm{g} / \mathrm{L}$, that matched the minimum criteria for selection, namely $\mathrm{r}^{2} \geq 0.5$ for fitting and $\mathrm{r}^{2} \geq 0.4$ for validation. The models were fitted with field reflectance and chla data from Dataset 2 and validated with chla from the other datasets and with the surface reflectance from MODIS products MOD09GA and MYD09GA.

\begin{tabular}{|c|c|c|c|c|c|c|}
\hline \multirow{2}{*}{$\#$} & \multirow{2}{*}{ Chla Predictive Model } & \multicolumn{2}{|c|}{ Fitting } & \multicolumn{3}{|c|}{ Validation } \\
\hline & & $\mathbf{n}$ & $\mathbf{r}^{2}$ & $\mathbf{n}$ & $\mathbf{r}^{2}$ & RMSE \\
\hline 1 & $1624 \times \exp \left(-0.005497 \times \mathrm{R}-993.9 \times \mathrm{G}^{-1}\right)$ & 18 & 0.59 & 86 & 0.62 & 18.1 \\
\hline 2 & $118-115.3 \times \mathrm{R} / \mathrm{G}-4084 \times \mathrm{R}^{-1}$ & 18 & 0.50 & 86 & 0.60 & 20.7 \\
\hline 3 & $88.87-0.1015 \times \mathrm{R}^{2} / \mathrm{G}-14,170 \times \mathrm{G}^{-1}$ & 18 & 0.65 & 86 & 0.58 & 19.8 \\
\hline 4 & $108.8-0.1045 \times \mathrm{R}-17,160 \times 1 / \mathrm{G}$ & 18 & 0.66 & 86 & 0.55 & 20.1 \\
\hline 5 & $171.4 \times \exp \left(-0.004107 \times \mathrm{R}^{2} / \mathrm{G}-222.7 \times \mathrm{R}^{-1}\right)$ & 18 & 0.70 & 86 & 0.53 & 22.5 \\
\hline 6 & $108.1-0.1958 \times \mathrm{Rh}-17,390 \times \mathrm{G}^{-1}$ & 18 & 0.66 & 86 & 0.46 & 21.3 \\
\hline 7 & $66.19-0.07716 \times \mathrm{R}^{2} / \mathrm{G}-3507 \times \mathrm{R}^{-1}$ & 18 & 0.52 & 86 & 0.41 & 23.4 \\
\hline
\end{tabular}

$\mathrm{G}$ and $\mathrm{R}$ stand for the reflectance in the green and red bands. Rh (model \#6) stands for the height of the reflectance in the red over a baseline between the blue and near infrared bands.

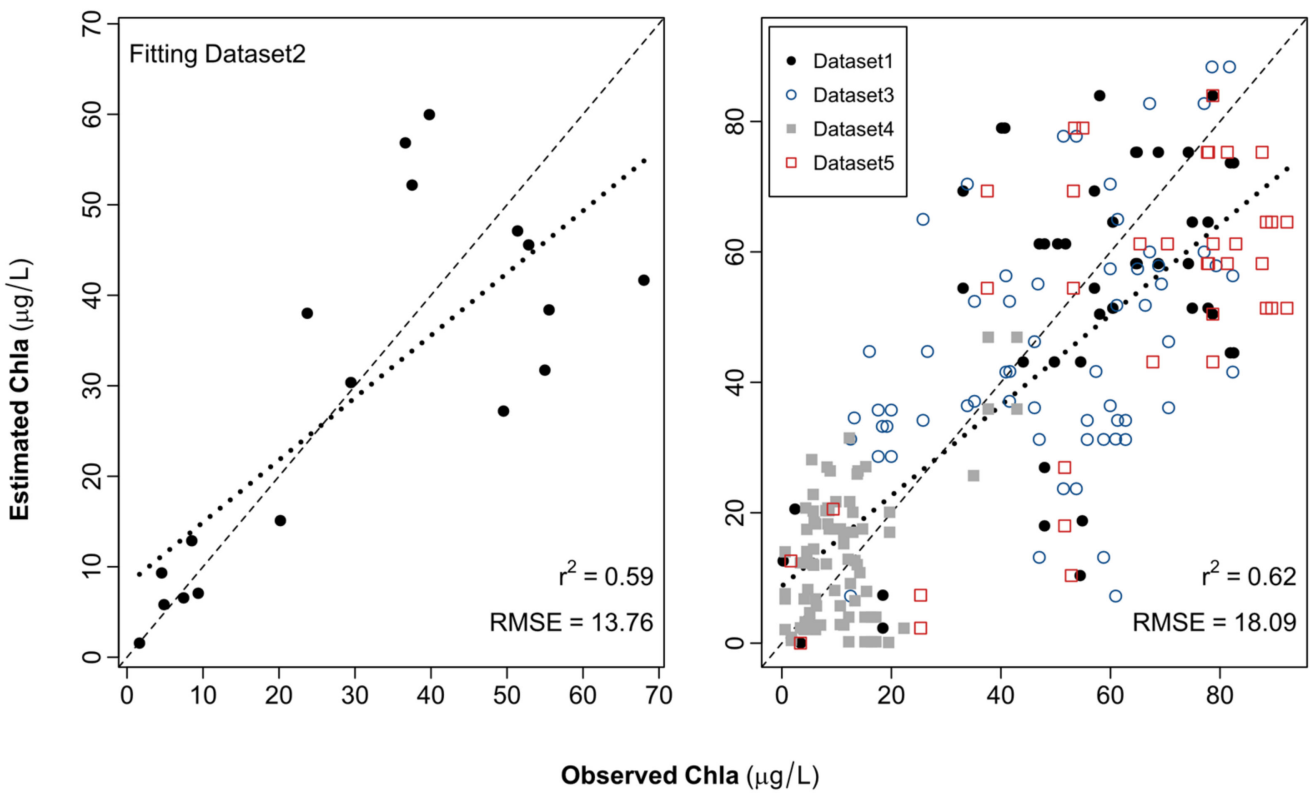

Figure 3. The selected model (\#1, Table 4) for chlorophyll-a (chla) estimation from the MODIS images. The model was fitted with field reflectance data and chla data from Dataset 2 and validated with the remaining datasets and with reflectance data from the MODIS images of the same day of the chla data. The dashed lines illustrate the 1:1 ratio and the dotted ones are the line of best fit.

\subsection{Time Series}

The model \#1 (Table 4, Figure 3) was applied to the reflectance data extracted from daily MODIS images (MOD09GA and MYD09GA) in the 2000-2020 period for all the study lakes. Not surprisingly, the frequency of successfully retrieved data was higher for the three largest lakes (Table 5), which we selected for the temporal analyses of the relationship between chla and the hydraulic regime (Figure 4). From the chla series, we generated an 
annual series of the trophic state (Figure 5). Both time series show that EARG is almost permanently eutrophic, whereas Castanhão was mesotrophic most of the time, and Orós had a short period of mesotrophic state but was majority eutrophic. The historical mean and standard deviation of chla in these lakes were $51 \pm 20,12 \pm 17$ and $39 \pm 23 \mu \mathrm{g} / \mathrm{L}$, respectively. The time series also showed that during rainy periods when the water volume rises quickly, the chla values fall quickly as well, such as in 2004.

Table 5. Comparison of the frequency of daily estimated chlorophyll- $a$ data that were successfully retrieved from MODIS images. The period of comparison (1 January 2005-31 December 2011, 2555 days) was chosen to avoid periods when some man-made lakes were dry or still under construction.

\begin{tabular}{lccc}
\hline Lake & Records & Freq. (\%) & Records/Month \\
\hline Eng. Armando Ribeiro Gonçalves (EARG) & 1620 & 63 & 19.3 \\
Orós (OROS) & 1463 & 57 & 17.4 \\
Castanhão (CAST) & 929 & 36 & 11.1 \\
Pacajus (PACJ) & 588 & 23 & 7.0 \\
Piató (PIAT) & 532 & 21 & 6.3 \\
Santa Cruz do Apodi (SCAP) & 503 & 20 & 6.0 \\
Pacoti (PACT) & 394 & 15 & 4.7 \\
Boqueirão de Pedras Brancas (PEDB) & 357 & 14 & 4.3 \\
Mendobim (MEND) & 273 & 11 & 3.3 \\
Umari (UMAR) & 143 & 6 & 1.7 \\
Banabuiú (BANB) & 138 & 5 & 1.6 \\
Aracoiaba (ARAC) & 98 & 4 & 1.2 \\
Malcozinhado (MALC) & 64 & 3 & 0.8 \\
\hline
\end{tabular}

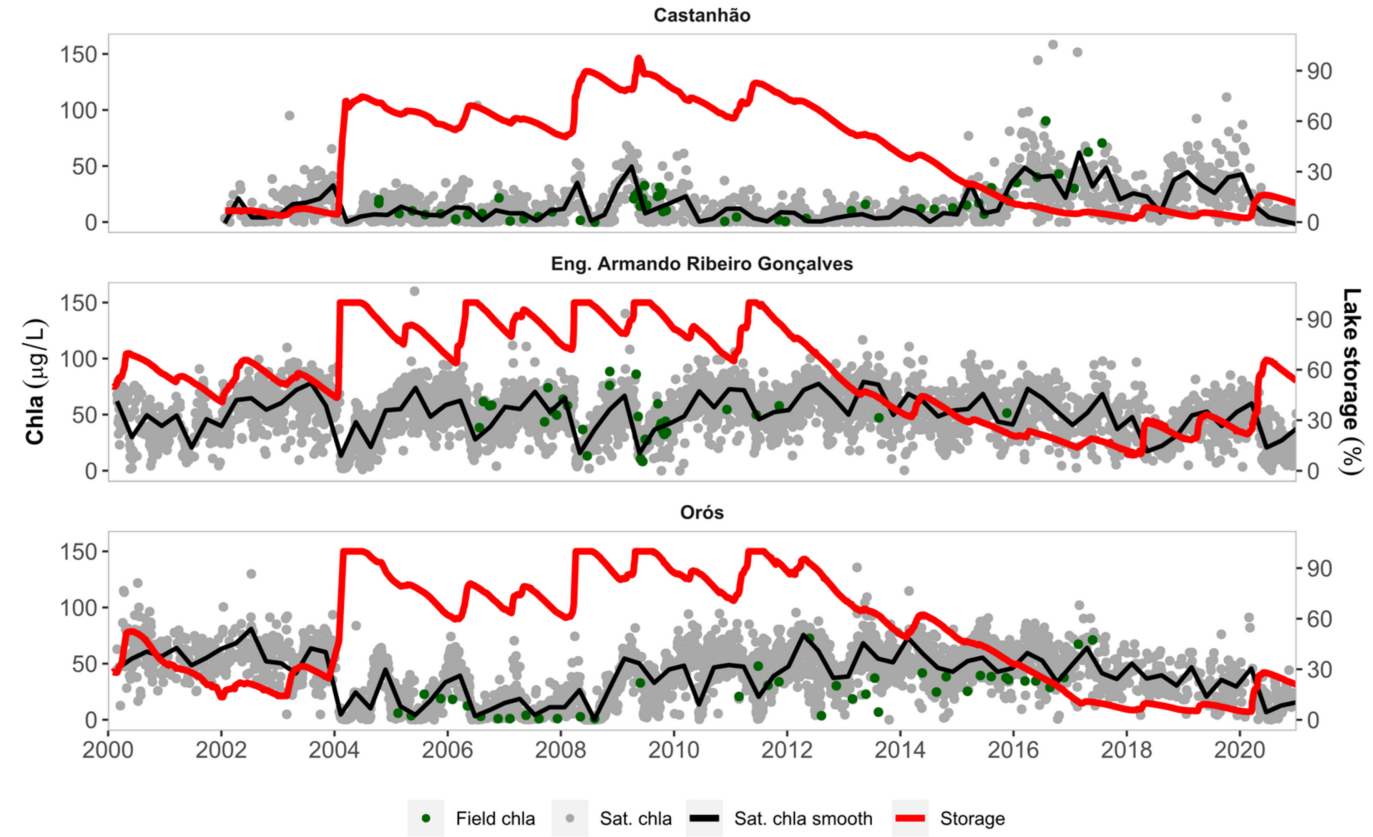

Figure 4. Daily series of the estimated chlorophyll-a concentration (chla) in the three largest study lakes. A smooth line for the chla estimations is shown. The field chla observations and the daily records of lake storage, in percent of the storage capacity, are also shown. The Castanhão series start later than the others because the dam was under construction until late 2002. 


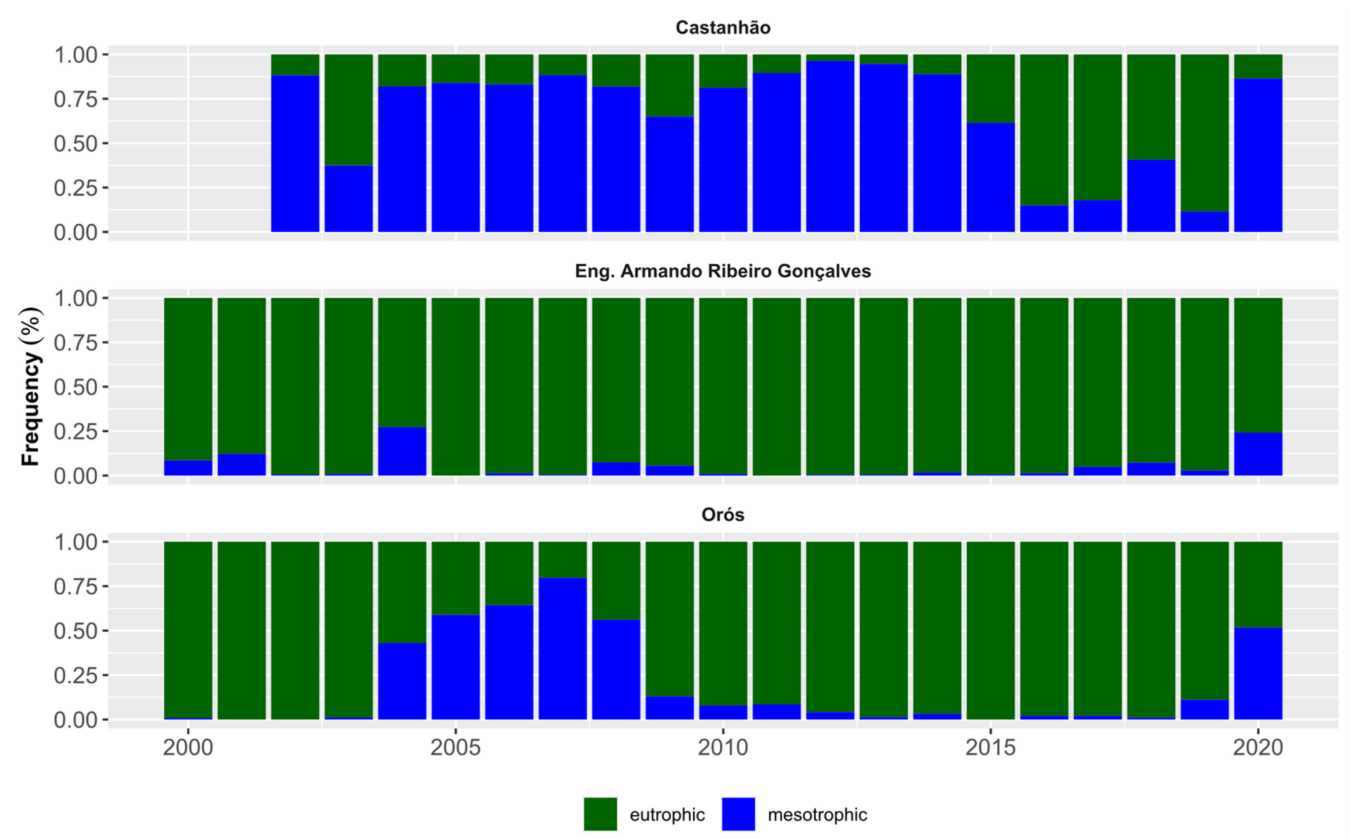

Figure 5. The annual relative frequency of eutrophic and mesotrophic states in the three largest study lakes.

\subsection{Hydraulic Effects}

The hydraulic effects on the chla is depicted below in the relationship between chla variation and water renewal rate in 15 days (Figure 6). Under low water renewal, chla may exhibit large fluctuations, whereas under higher renewal rates ( $>25 \%$ in 15 days), chla variation is zero or negative. It is worthy to note that in EARG, which has an almost permanent eutrophic state and is the lake with the highest mean chla, the water renewal rates did not reach values as high as in the other lakes.

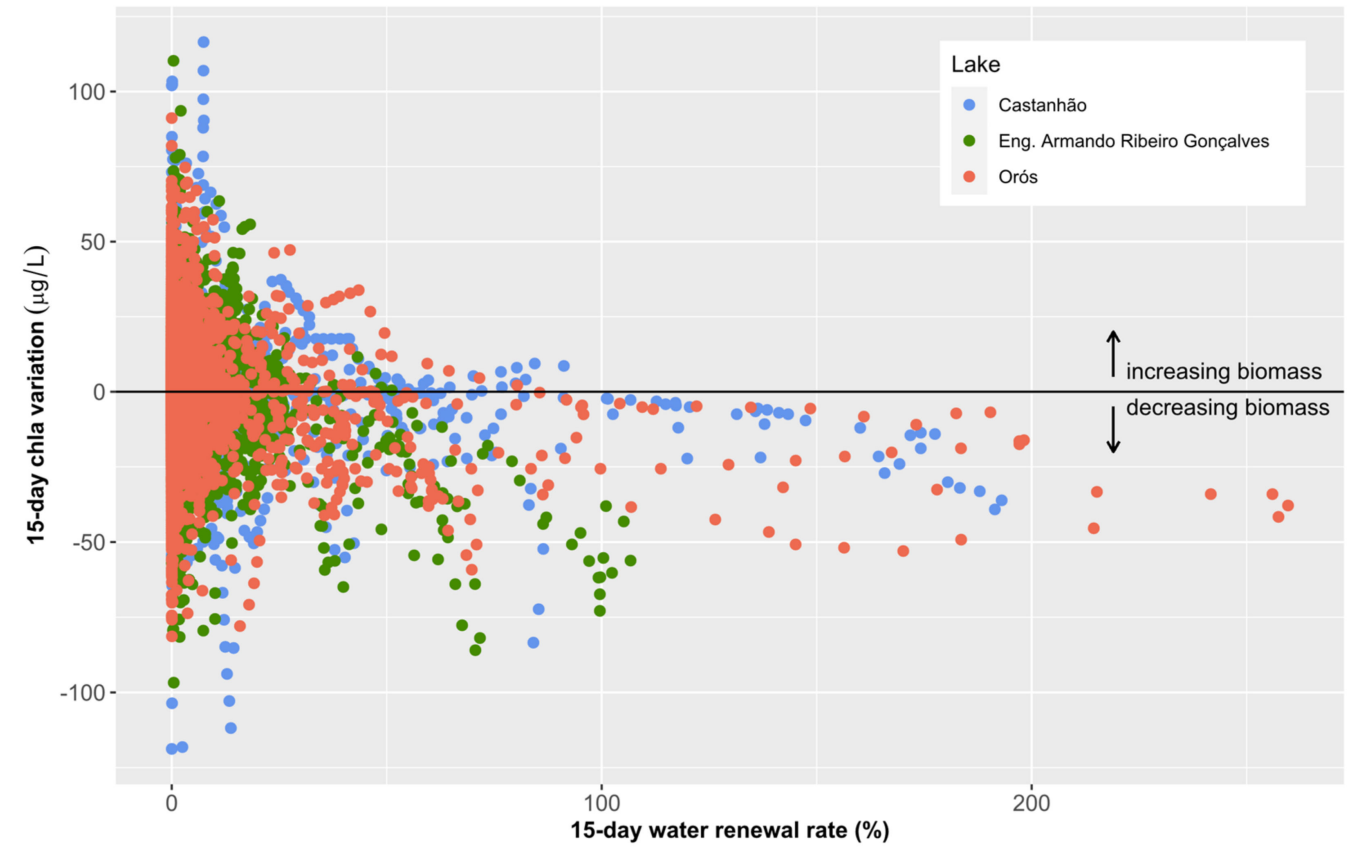

Figure 6. Chlorophyll $a$ (chla) variation in 15-day periods as a function of the water renewal rate, calculated as the total water inflow divided by the median stored volume in the same periods. 


\section{Discussion}

The estimation of the chlorophyll-a concentration (chla) from daily MODIS imagery allowed us to produce long-term time series for the three largest study lakes. Although the remote chla data is certainly less accurate than field observations, the produced series have a much higher temporal resolution ( $>10$ records/month) than the series that were derived from the conventional monitoring programs in the Brazilian semiarid region, whose sampling frequency vary from monthly to quarterly.

Of course, not all lakes can benefit from MODIS-based monitoring, as clearly shown by the few successful chla estimations in Malcozinhado, the smallest study lake. In addition to the lake's surface area, its morphology and the presence of islands and peninsulas can negatively interfere as well. For such cases, MODIS bands will carry much noise due to a spectral mixture and adjacency effects. This can be minimized through spectral unmixing procedures $[48,49]$, which we have not tested though. For most of the lakes, a mean frequency of at least three records/month was achieved.

The selected model, as well as the others in Table 4, included the reflectance in the green and red bands. These two bands seem to be more appropriate for chla assessment in turbid waters than the blue band because the reflectance in the latter is strongly affected by light absorption processes from colored dissolved organic matter and suspended inorganic material [50], not to mention its greater vulnerability to atmospheric interference [51]. In Case 2 waters, the simple blue-green ratio that is used over open oceanic waters, will not work [52]. The BNDBI algorithm [22], proposed by Zhang et al. for chla estimation in turbid waters from MODIS images, is based on the normalized green-red difference, that was taken in relation to a baseline between the blue and near-infrared bands. Despite its promising original results, the algorithm was not successful with our data. We believe it was a matter of scale. The BNDBI algorithm was developed and validated for a very large chla range (10-1000 $\mu \mathrm{g} / \mathrm{L})$. Our data have a much narrower chla range $(0-100 \mu \mathrm{g} / \mathrm{L})$. For this limited range, the relation between BNDBI and chla has a larger uncertainty than for the $100-1000 \mu \mathrm{g} / \mathrm{L}$ range, as revealed by the data dispersion in Figure $2 \mathrm{c}$ of their article. Another important difference is that they did not use atmospherically-corrected MODIS products as we did.

An important methodological consideration refers to the differences among the analytical protocols for chla determination of the datasets we used. The different membrane filters and extraction solvents that were used were a likely source of uncertainty when comparing the results among datasets. Equal methods are certainly preferable when comparing or combining data sets, but it is very difficult to achieve such homogeneity in environmental monitoring programs in developing countries. However, this methodological drawback may well be seen as an indication of the robustness of the validated model.

Still on the methodology, it must be mentioned that empirical models are often limited to particular sites and/or sensors [53]. Furthermore, our validation dataset was restricted to the $0-100 \mu \mathrm{g} / \mathrm{L}$ concentration range. As such, the operational application of the selected model to other lakes that were not included in this study or with higher concentrations would require an extra validation effort. On the other hand, empirical models are of easy application and, in spite of their limitations, may have good accuracy and may even tolerate seasonal variations in the phytoplankton composition [54].

A quick look at the produced time series shows that the three lakes exhibit quite distinct trophic state histories. Eng. Armando Ribeiro Gonçalves (EARG) is almost all the time under eutrophic conditions, Castanhão was mostly mesotrophic until 2015, and Orós had prevalent mesotrophic conditions in 2005-2008 and 2020 but was eutrophic most of the time. As shown in Figure 6, EARG did not have water renewal rates as high as the other two, which is a possible explanation for the resilience of its eutrophic state. However, a more attentive look at both the chla and lake storage time series reveals interesting common patterns. A steep rise in water level is often accompanied by an abrupt descent in chla, as dramatically seen in 2004, a very rainy year in which man-made lakes across the region overflowed. The decline in chla was probably a joint effect of biomass dilution by the 
inflowing water, biomass loss in the outflowing water, and light attenuation by suspended solids whose concentration increases during rainy events [26,55-61]. Although less dramatic, the same pattern can be seen in the rainy seasons of 2006-2011. Another pattern is the tendency of chla rising and keeping high during dry periods. That was especially evident during the multiannual drought that began in 2012, which appeared to favor a stable maintenance of high chla values until the rainy season of 2020. Similar temporal dynamics were observed in a 16-year study in the North Pine Dam [59], an Australian man-made semiarid lake with high interannual variability in the hydraulic regime.

The described patterns were not unexpected since the hydraulic regime of a lake plays a major role in the phytoplankton temporal dynamics, with low water renewal rates favoring phytoplankton biomass accumulation and high renewal rates having the opposite effect [23,58-64]. The significant water renewal in 2004 temporally shifted the trophic state of EARG and Orós. In the latter, this effect even persisted trough the subsequent years, as also observed in the cited North Pine Dam study [59]. It is worthy of mention, though, that when the water inflow is not enough to promote a thorough water renewal, it may act in the opposite way, bringing nutrients to the lake and favoring phytoplankton growth $[65,66]$. That is probably why not all the rainy seasons led to a significant fall in the phytoplankton biomass. On the other hand, the dry periods clearly favored the phytoplankton biomass accumulation. A clear shift in the trophic state of Castanhão is apparent from 2015 on, likely as a result of the severe drought that began in 2012. Extended dry periods were shown to favor phytoplankton biomass accumulation also in other studies in the region $[24,26,61,67,68]$ and low water renewal rates or reduced water levels have been associated with poorer water quality in man-made lakes elsewhere [57,64,69-71].

Due to climate changes, longer dry periods are expected to occur in the Brazilian semiarid region with some simulations showing a reduced water volume in large manmade lakes of this region $[27,72]$. Except for extreme droughts when the water level is so low that the inorganic suspended solids reduces light availability and favors mixotrophic plankton over cyanobacteria [73], a drier scenario worsens the water quality and increases phytoplankton biomass, with dominance of potentially toxic cyanobacteria [26,60]. The persistence of high biomass during the droughts of 2001-2003 and 2012-2019 supports such a prediction. The "flushing" that is promoted by dam overflow, an important densityindependent mechanism controlling the phytoplankton biomass [26,58-60], is expected to become a rarer event in a dryer regional climate. That will demand drastic improvements on the water quality management and monitoring.

Our results demonstrated the great, and somewhat underestimated, potential of the MODIS archive for studying the temporal dynamics of the phytoplankton biomass in natural and man-made lakes. Even though the MODIS bands 1-7 were not designed for water remote sensing, they are generally more suitable than its ocean color bands for studying inland water bodies. Sensors such as those aboard of the missions Sentinel-2 and Sentinel-3 from the European Spatial Agency, are currently the most promising options for limnological studies, but the extensive MODIS archive, with daily images dating back to 2000, will remain a quite valuable source of data. We encourage the use of its archive for studying lakes in the Brazilian semiarid region and elsewhere.

Supplementary Materials: The following are available online at https://www.mdpi.com/article/10 $.3390 / w 14030400 /$ s1, Figure S1: Remote sensing reflectance data collected in the study lakes between 2008 and 2015, Figure S2: Three-band model used to generate Dataset 3, Figure S3: best fitted model for the MODIS data simulated from field reflectance data.

Author Contributions: Conceptualization, D.L.T.V., J.-M.M. and J.L.d.A.; methodology, D.L.T.V., J.-M.M. and J.L.d.A.; software, D.L.T.V.; validation, J.-M.M.; formal analysis, D.L.T.V., J.-M.M., J.L.d.A., L.S.M. and N.B.; investigation, D.L.T.V., J.-M.M., J.L.d.A., E.S.P.R.M., L.S.M. and N.B.; resources, J.L.d.A., E.S.P.R.M., L.S.M. and N.B.; data curation, D.L.T.V., J.-M.M. and J.L.d.A.; writing-original draft preparation, D.L.T.V.; writing-review and editing, J.-M.M., J.L.d.A., E.S.P.R.M., L.S.M. and N.B.; visualization, D.L.T.V.; supervision, J.-M.M.; project administration, J.-M.M., J.L.d.A. and E.S.P.R.M.; 
funding acquisition, J.-M.M. and E.S.P.R.M. All authors have read and agreed to the published version of the manuscript.

Funding: This study was funded in part by the Coordination of Improvement of Higher Education Personnel (Capes) (Finance Code 001) and by the Brazilian Council for Scientific and Technological Development (CNPq), as a project named "Monitoramento da eutrofização dos açudes do Nordeste por sensoriamento remoto", Ref. 490688/2010-1.

Data Availability Statement: The datasets that were used in this study as well as scripts and $\mathrm{kml}$ files are openly available in FigShare at https:/ / doi.org/10.6084/m9.figshare.16746499.v1 (accessed on 20 December 2021).

Acknowledgments: The authors thank for the operational support from the National Water and Sanitation Agency (ANA), the Federal University of Rio Grande do Norte (UFRN), the Research Institute in Meteorology and Water Resources (Funceme), and the Water Resources Management Company (Cogerh), as well as for the contributions of Edson Santana, Raúl Espinoza Villar, Rosemberg Menezes, Walt Disney Paulino, Francimeyre Freire Avelino, Deilton Holanda, Porfírio Sales Neto, and many other professionals.

Conflicts of Interest: The authors declare no conflict of interest. The funders had no role in the design of the study; in the collection, analyses, or interpretation of data; in the writing of the manuscript, or in the decision to publish the results.

\section{References}

1. Smith, V.H. Eutrophication of freshwater and coastal marine ecosystems: A global problem. Environ. Sci. Pollut. Res. Int. 2003, 10, 126-139. [CrossRef] [PubMed]

2. Glibert, P.M. Eutrophication, harmful algae and biodiversity-Challenging paradigms in a world of complex nutrient changes. Mar. Pollut. Bull. 2017, 124, 591-606. [CrossRef]

3. Carvalho, L.; Poikane, S.; Lyche Solheim, A.; Phillips, G.; Borics, G.; Catalan, J.; De Hoyos, C.; Drakare, S.; Dudley, B.J.; Järvinen, M.; et al. Strength and uncertainty of phytoplankton metrics for assessing eutrophication impacts in lakes. Hydrobiologia 2013, 704, 127-140. [CrossRef]

4. $\quad$ Özkan, K.; Jeppesen, E.; Davidson, T.A.; Bjerring, R.; Johansson, L.S.; Søndergaard, M.; Lauridsen, T.L.; Svenning, J.C. Long-term trends and temporal synchrony in plankton richness, diversity and biomass driven by re-oligotrophication and climate across 17 Danish Lakes. Water 2016, 8, 427. [CrossRef]

5. Thackeray, S.J.; Jones, I.D.; Maberly, S.C. Long-term change in the phenology of spring phytoplankton: Species-specific responses to nutrient enrichment and climatic change. J. Ecol. 2008, 96, 523-535. [CrossRef]

6. Dubelaar, G.B.J.; Geerders, P.J.F.; Jonker, R.R. High frequency monitoring reveals phytoplankton dynamics. J. Environ. Monit. 2004, 6, 946-952. [CrossRef] [PubMed]

7. $\quad$ Bowes, M.J.; Loewenthal, M.; Read, D.S.; Hutchins, M.G.; Prudhomme, C.; Armstrong, L.K.; Harman, S.A.; Wickham, H.D.; Gozzard, E.; Carvalho, L. Identifying multiple stressor controls on phytoplankton dynamics in the River Thames (UK) using high-frequency water quality data. Sci. Total Environ. 2016, 569-570, 1489-1499. [CrossRef]

8. Strobl, R.O.; Robillard, P.D. Network design for water quality monitoring of surface freshwaters: A review. J. Environ. Manag. 2008, 87, 639-648. [CrossRef]

9. Shutler, J.D.; Land, P.E.; Smyth, T.J.; Groom, S.B. Extending the MODIS 1-km ocean colour atmospheric correction to the MODIS 500-m bands and 500-m chlorophyll-a estimation towards coastal and estuarine monitoring. Remote Sens. Environ. 2007, 107, 521-532. [CrossRef]

10. Shi, K.; Zhang, Y.; Zhu, G.; Liu, X.; Zhou, Y.; Xu, H.; Qin, B.; Liu, G.; Li, Y. Long-term remote monitoring of total suspended matter concentration in Lake Taihu using 250 m MODIS-Aqua data. Remote Sens. Environ. 2015, 164, 43-56. [CrossRef]

11. Espinoza Villar, R.; Martinez, J.-M.; Guyot, J.-L.; Fraizy, P.; Armijos, E.; Crave, A.; Bazán, H.; Vauchel, P.; Lavado, W. The integration of field measurements and satellite observations to determine river solid loads in poorly monitored basins. J. Hydrol. 2012, 444-445, 221-228. [CrossRef]

12. Wang, S.; Li, J.; Zhang, B.; Lee, Z.; Spyrakos, E.; Feng, L.; Liu, C.; Zhao, H.; Wu, Y.; Zhu, L.; et al. Changes of water clarity in large lakes and reservoirs across China observed from long-term MODIS. Remote Sens. Environ. 2020, 247, 111949. [CrossRef]

13. Chakraborty, K.; Gupta, A.; Lotliker, A.A.; Tilstone, G. Evaluation of model simulated and MODIS-Aqua retrieved sea surface chlorophyll in the eastern Arabian Sea. Estuar. Coast. Shelf Sci. 2016, 181, 61-69. [CrossRef]

14. Sarangi, R.K.; Devi, K.N. Space-based observation of chlorophyll, sea surface temperature, nitrate, and sea surface height anomaly over the Bay of Bengal and Arabian Sea. Adv. Sp. Res. 2017, 59, 33-44. [CrossRef]

15. Modabberi, A.; Noori, R.; Madani, K.; Ehsani, A.H.; Danandeh Mehr, A.; Hooshyaripor, F.; Kløve, B. Caspian Sea is eutrophying: The alarming message of satellite data. Environ. Res. Lett. 2019, 15, 124047. [CrossRef] 
16. Hu, C.; Feng, L.; Lee, Z.; Davis, C.O.; Mannino, A.; McClain, C.R.; Franz, B.A. Dynamic range and sensitivity requirements of satellite ocean color sensors: Learning from the past. Appl. Opt. 2012, 51, 6045. [CrossRef]

17. Tarrant, P.E.; Amacher, J.A.; Neuer, S. Assessing the potential of Medium-Resolution Imaging Spectrometer (MERIS) and Moderate-Resolution Imaging Spectroradiometer (MODIS) data for monitoring total suspended matter in small and intermediate sized lakes and reservoirs. Water Resour. Res. 2010, 46, 1-7. [CrossRef]

18. De Moraes Novo, E.M.L.; de Farias Barbosa, C.C.; Freitas, R.M.; Shimabukuro, Y.E.; Melack, J.M.; Pereira-Filho, W. Seasonal changes in chlorophyll distributions in Amazon floodplain lakes derived from MODIS images. Limnology 2006, 7, 153-161. [CrossRef]

19. Zhang, Y.; Lin, S.; Qian, X.; Wang, Q.; Qian, Y.; Liu, J.; Ge, Y. Temporal and spatial variability of chlorophyll a concentration in Lake Taihu using MODIS time-series data. Hydrobiologia 2011, 661, 235-250. [CrossRef]

20. Ogashawara, I.; Alcântara, E.H.; Curtarelli, M.P.; Adami, M.; Nascimento, R.F.F.; Souza, A.F.; Stech, J.L.; Kampel, M. Performance analysis of MODIS 500-m spatial resolution products for estimating chlorophyll-a concentrations in oligo- to meso-trophic waters case study: Itumbiara reservoir, Brazil. Remote Sens. 2014, 6, 1634-1653. [CrossRef]

21. Lins, R.; Martinez, J.-M.; Motta Marques, D.; Cirilo, J.; Medeiros, P.; Fragoso Júnior, C. A Multivariate Analysis Framework to Detect Key Environmental Factors Affecting Spatiotemporal Variability of Chlorophyll-a in a Tropical Productive EstuarineLagoon System. Remote Sens. 2018, 10, 853. [CrossRef]

22. Zhang, Y.; Ma, R.; Duan, H.; Loiselle, S.; Zhang, M.; Xu, J. A novel MODIS algorithm to estimate chlorophyll a concentration in eutrophic turbid lakes. Ecol. Indic. 2016, 69, 138-151. [CrossRef]

23. Bouvy, M.; Falcão, D.; Marinho, M.; Pagano, M.; Moura, A. Occurrence of Cylindrospermopsis (Cyanobacteria) in 39 Brazilian tropical reservoirs during the 1998 drought. Aquat. Microb. Ecol. 2000, 23, 13-27. [CrossRef]

24. Costa, I.A.S.; Cunha, S.R.D.S.; Panosso, R.; Araújo, M.F.F.; Melo, J.L.d.S.; Eskinazi-Sant'Anna, E.M. Dinâmica de Cianobactérias em reservatórios eutróficos do semi-árido do Rio Grande do Norte. Oecologia Aust. 2009, 13, 382-401. [CrossRef]

25. Huszar, V.; Silva, L.; Marinho, M.; Domingos, P.; Sant'Anna, C. Cyanoprokaryote assemblages in eight productive tropical Brazilian waters. Hydrobiologia 2000, 424, 67-77. [CrossRef]

26. Brasil, J.; Attayde, J.L.; Vasconcelos, F.R.; Dantas, D.D.F.; Huszar, V.L.M. Drought-induced water-level reduction favors cyanobacteria blooms in tropical shallow lakes. Hydrobiologia 2016, 770, 145-164. [CrossRef]

27. Krol, M.S.; Bronstert, A. Regional integrated modelling of climate change impacts on natural resources and resource usage in semi-arid Northeast Brazil. Environ. Model. Softw. 2007, 22, 259-268. [CrossRef]

28. Uvo, C.B.; Repelli, C.A.; Zebiak, S.E.; Kushnir, Y. The relationships between tropical Pacific and Atlantic SST and northeast Brazil monthly precipitation. J. Clim. 1998, 11, 551-562. [CrossRef]

29. Medeiros, P.H.A.; Araújo, J.C. de Temporal variability of rainfall in a semiarid environment in Brazil and its effect on sediment transport processes. J. Soils Sediments 2014, 14, 1216-1223. [CrossRef]

30. Barbosa, J.E.d.L.; Medeiros, E.S.F.; Brasil, J.; Cordeiro, R.d.S.; Crispim, M.C.B.; da Silva, G.H.G. Aquatic systems in semi-arid Brazil: Limnology and management. Acta Limnol. Bras. 2012, 24, 103-118. [CrossRef]

31. COGERH. Anuário do Monitoramento Quantitativo dos Principais Açudes do Estado do Ceará: 2017; COGERH: Fortaleza, Brazil, 2018

32. Stich, H.B.; Brinker, A. Less is better: Uncorrected versus pheopigment-corrected photometric chlorophyll-a estimation. Arch. Hydrobiol. 2005, 162, 111-120. [CrossRef]

33. Jespersen, A.M.; Christoffersen, K. Measurements of chlorophyll-a from phytoplankton using ethanol as extraction solvent. Arch. Hydrobiol. 1987, 109, 445-454.

34. Jeffrey, S.W.; Humphrey, G.F. New spectrophotometric equations for determining chlorophylls a, b, c1 and c2 in higher plants, algae and natural phytoplankton. Biochem. Physiol. Pflanz. 1975, 167, 191-194. [CrossRef]

35. APHA; AWWA; WEF. Standard Methods for the Examination of Water and Wastewater, 21st ed.; American Public Health Association: Washington, DC, USA, 2005.

36. Mobley, C.D. Estimation of the remote-sensing reflectance from above-surface measurements. Appl. Opt. 1999, $38,7442-7455$. [CrossRef]

37. Vermote, E. MOD09A1 MODIS/Terra Surface Reflectance 8-Day L3 Global 500 m SIN Grid V006. Available online: http: / / doi.org/10.5067/MODIS/MOD09A1.006 (accessed on 20 December 2021).

38. Gorelick, N.; Hancher, M.; Dixon, M.; Ilyushchenko, S.; Thau, D.; Moore, R. Google Earth Engine: Planetary-scale geospatial analysis for everyone. Remote Sens. Environ. 2017, 202, 18-27. [CrossRef]

39. Wang, S.; Li, J.; Zhang, B.; Shen, Q.; Zhang, F.; Lu, Z. A simple correction method for the MODIS surface reflectance product over typical inland waters in China. Int. J. Remote Sens. 2016, 37, 6076-6096. [CrossRef]

40. Allan, M.G.; Hamilton, D.P.; Hicks, B.J.; Brabyn, L. Landsat remote sensing of chlorophyll a concentrations in central North Island lakes of New Zealand. Int. J. Remote Sens. 2011, 32, 2037-2055. [CrossRef]

41. Brezonik, P.; Menken, K.D.; Bauer, M. Landsat-based remote sensing of lake water quality characteristics, including chlorophyll and colored dissolved organic matter (CDOM). Lake Reserv. Manag. 2005, 21, 373-382. [CrossRef]

42. Lim, J.; Choi, M. Assessment of water quality based on Landsat 8 operational land imager associated with human activities in Korea. Environ. Monit. Assess. 2015, 187, 1-17. [CrossRef] [PubMed]

43. Nazeer, M.; Nichol, J.E. Development and application of a remote sensing-based Chlorophyll-a concentration prediction model for complex coastal waters of Hong Kong. J. Hydrol. 2016, 532, 80-89. [CrossRef] 
44. Gitelson, A.A.; Schalles, J.F.; Hladik, C.M. Remote chlorophyll-a retrieval in turbid, productive estuaries: Chesapeake Bay case study. Remote Sens. Environ. 2007, 109, 464-472. [CrossRef]

45. Le, C.; Li, Y.; Zha, Y.; Sun, D.; Huang, C.; Lu, H. A four-band semi-analytical model for estimating chlorophyll a in highly turbid lakes: The case of Taihu Lake, China. Remote Sens. Environ. 2009, 113, 1175-1182. [CrossRef]

46. Thornton, J.; Rast, W. A test of hypotheses relating to the comparative limnology and assessment of eutrophication in semi-arid man-made lakes. In Comparative Reservoir Limnology and Water Quality Management; Straskraba, M., Tundisi, J., Duncan, A., Eds.; Springer: Dordrecht, The Netherlands, 1993; pp. 1-24.

47. Cunha, D.G.F.; do Carmo Calijuri, M.; Lamparelli, M.C. A trophic state index for tropical/subtropical reservoirs (TSItsr). Ecol. Eng. 2013, 60, 126-134. [CrossRef]

48. Ma, B.; Wu, L.; Zhang, X.; Li, X.; Liu, Y.; Wang, S. Locally adaptive unmixing method for lake-water area extraction based on MODIS $250 \mathrm{~m}$ bands. Int. J. Appl. Earth Obs. Geoinf. 2014, 33, 109-118. [CrossRef]

49. Gebru, H.G.; Melesse, A.M.; Gebremariam, A.G. Double-stage linear spectral unmixing analysis for improving accuracy of sediment concentration estimation from MODIS data: The case of Tekeze River, Ethiopia. Model. Earth Syst. Environ. 2020, 6, 407-416. [CrossRef]

50. Le, C.; Hu, C.; English, D.; Cannizzaro, J.; Chen, Z.; Feng, L.; Boler, R.; Kovach, C. Towards a long-term chlorophyll-a data record in a turbid estuary using MODIS observations. Prog. Oceanogr. 2013, 109, 90-103. [CrossRef]

51. Zhang, M.; Ma, R.; Li, J.; Zhang, B.; Duan, H. A validation study of an improved SWIR iterative atmospheric correction algorithm for MODIS-aqua measurements in lake Taihu, China. IEEE Trans. Geosci. Remote Sens. 2014, 52, 4686-4695. [CrossRef]

52. Gitelson, A.A.; Dall'Olmo, G.; Moses, W.J.; Rundquist, D.C.; Barrow, T.; Fisher, T.R.; Gurlin, D.; Holz, J. A simple semi-analytical model for remote estimation of chlorophyll-a in turbid waters: Validation. Remote Sens. Environ. 2008, 112, 3582-3593. [CrossRef]

53. Dörnhöfer, K.; Oppelt, N. Remote sensing for lake research and monitoring-Recent advances. Ecol. Indic. 2016, 64, 105-122. [CrossRef]

54. Ligi, M.; Kutser, T.; Kallio, K.; Attila, J.; Koponen, S.; Paavel, B.; Soomets, T.; Reinart, A. Testing the performance of empirical remote sensing algorithms in the Baltic Sea waters with modelled and in situ reflectance data. Oceanologia 2017, 59, 57-68. [CrossRef]

55. Angelini, R.; Bini, L.M.; Starling, F.L.R.M. Efeitos de diferentes intervenções no processo de eutrofização do lago Paranoá (Brasília-DF). Oecologia Aust. 2008, 12, 564-571. [CrossRef]

56. Vanni, M.J.; Andrews, J.S.; Renwick, W.H.; Gonzalez, M.J.; Noble, S.J. Nutrient and light limitation of reservoir phytoplankton in relation to storm-mediated pulses in stream discharge. Arch. Hydrobiol. 2006, 167, 421-445. [CrossRef]

57. Naselli-Flores, L. Man-made lakes in Mediterranean semi-arid climate: The strange case of Dr Deep Lake and Mr Shallow Lake. Hydrobiologia 2003, 506-509, 13-21. [CrossRef]

58. Rangel, L.M.; Silva, L.H.S.; Rosa, P.; Roland, F.; Huszar, V.L.M. Phytoplankton biomass is mainly controlled by hydrology and phosphorus concentrations in tropical hydroelectric reservoirs. Hydrobiologia 2012, 693, 13-28. [CrossRef]

59. Harris, G.P.; Baxter, G. Interannual variability in phytoplankton biomass and species composition in a subtropical reservoir. Freshw. Biol. 1996, 35, 545-560. [CrossRef]

60. De Castro Medeiros, L.; Mattos, A.; Lürling, M.; Becker, V. Is the future blue-green or brown? The effects of extreme events on phytoplankton dynamics in a semi-arid man-made lake. Aquat. Ecol. 2015, 49, 293-307. [CrossRef]

61. Bouvy, M.; Nascimento, S.M.; Molica, R.J.R.; Ferreira, A.; Huszar, V.; Azevedo, S.M.F.O. Limnological features in Tapacurá reservoir (northeast Brazil) during a severe drought. Hydrobiologia 2003, 493, 115-130. [CrossRef]

62. Gomes, L.C.; Miranda, L.E. Hydrologic and climatic regimes limit phytoplankton biomass in reservoirs of the Upper Paraná River Basin, Brazil. Hydrobiologia 2001, 457, 205-214. [CrossRef]

63. Lins, R.P.M.; de Ceballos, B.S.O.; Lopez, L.C.S.; Barbosa, L.G. Phytoplankton functional groups in a tropical reservoir in the Brazilian semiarid region. Int. J. Trop. Biol. 2017, 65, 1129-1141. [CrossRef]

64. Soares, M.C.S.; Marinho, M.M.; Huszar, V.L.M.; Branco, C.W.C.; Azevedo, S.M.F.O. The effects of water retention time and watershed features on the limnology of two tropical reservoirs in Brazil. Lakes Reserv. Res. Manag. 2008, 13, 257-269. [CrossRef]

65. Abell, J.M.; Hamilton, D.P. Biogeochemical processes and phytoplankton nutrient limitation in the inflow transition zone of a large eutrophic lake during a summer rain event. Ecohydrology 2015, 8, 243-262. [CrossRef]

66. Calijuri, M.; Dos Santos, A. Temporal variations in phytoplankton primary production in a tropical reservoir (Barra Bonita, SP-Brazil). Hydrobiologia 2001, 445, 11-26. [CrossRef]

67. Costa, M.R.A.; Attayde, J.L.; Becker, V. Effects of water level reduction on the dynamics of phytoplankton functional groups in tropical semi-arid shallow lakes. Hydrobiologia 2016, 778, 75-89. [CrossRef]

68. Rocha-Jr, C.A.N.; Costa, M.R.A.; Menezes, R.F.; Attayde, J.L.; Becker, V. Water volume reduction increases eutrophication risk in tropical semi-arid reservoirs. Acta Limnol. Bras. 2018, 30. [CrossRef]

69. Noori, R.; Ansari, E.; Bhattarai, R.; Tang, Q.; Aradpour, S.; Maghrebi, M.; Torabi Haghighi, A.; Bengtsson, L.; Kløve, B. Complex dynamics of water quality mixing in a warm mono-mictic reservoir. Sci. Total Environ. 2021, 777, 146097. [CrossRef] [PubMed]

70. Noori, R.; Ansari, E.; Jeong, Y.W.; Aradpour, S.; Maghrebi, M.; Hosseinzadeh, M.; Bateni, S.M. Hyper-nutrient enrichment status in the sabalan lake, iran. Water 2021, 13, 2874. [CrossRef]

71. Naselli-Flores, L.; Barone, R. Water-level fluctuations in Mediterranean reservoirs: Setting a dewatering threshold as a management tool to improve water quality. Hydrobiologia 2005, 548, 85-99. [CrossRef] 
72. Marengo, J.A.; Jones, R.; Alves, L.M.; Valverde, M.C. Future change of temperature and precipitation extremes in South America as derived from the PRECIS regional climate modeling system. Int. J. Climatol. 2009, 29, 2241-2255. [CrossRef]

73. Costa, M.R.A.; Menezes, R.F.; Sarmento, H.; Attayde, J.L.; Sternberg, L.d.S.L.; Becker, V. Extreme drought favors potential mixotrophic organisms in tropical semi-arid reservoirs. Hydrobiologia 2019, 831, 43-54. [CrossRef] 